PART I. DISEASES AND PROBLEMS DISTINGUISHED BY WHO AND FAO DZIAŁ I. CHOROBY I PROBLEMY WYRÓŻNIONE PRZEZ WHO I FAO

\title{
HEALTH-RELATED BEHAVIORS OF SENIORS IN RURAL VERSUS URBAN AREAS: A CROSS-SECTIONAL STUDY
}

\section{ZACHOWANIA PROZDROWOTNE SENIORÓW MIESZKAJĄCYCH NA OBSZARACH WIEJSKICH I MIEJSKICH: BADANIE PRZEKROJOWE}

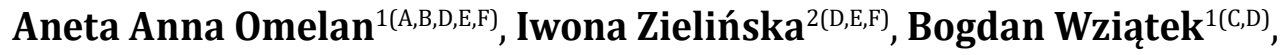 \\ Ernest Bielinis $^{3(B, D, E)}$, Robert Podstawski ${ }^{1(E, F)}$
}

\author{
${ }^{1}$ Department of Tourism, Recreation and Ecology, University of Warmia and Mazury in Olsztyn, Poland \\ ${ }^{2}$ Department of General Sociology and Interdisciplinary Research, \\ the Maria Grzegorzewska University in Warsaw, Poland \\ ${ }^{3}$ Department of Forestry and Forest Ecology, University of Warmia and Mazury in Olsztyn, Poland
}

Authors' contribution

Wkład autorów:

A. Study design/planning

zaplanowanie badań

B. Data collection/entry

zebranie danych

C. Data analysis/statistics

dane - analiza i statystyki

D. Data interpretation

interpretacja danych

E. Preparation of manuscript przygotowanie artykułu

F. Literature analysis/search wyszukiwanie i analiza literatury

G. Funds collection zebranie funduszy
Tables: 4

Figures: 0

References: 28

Submitted: 2020 Jan 27

Accepted: 2020 Feb 20

\section{Summary}

Background. In Polish cities, many organizations help senior citizens (60+), and many targeted programs support their healthcare. Rural areas, in contrast, have been very much neglected. The main goal of this study was to obtain data on selected health-related behaviors of seniors living in urban and rural areas. We compared exercise, eating habits, smoking and alcohol consumption. Material and methods. The study was conducted in Poland among people aged 60 and above living in remote rural areas $(n=128)$ and the city $(n=146)$. Interviews were used to conduct surveys and collect lifestyle data. The differences between urban and rural seniors were determined in a significance test of two structure coefficients at a significance level of $\alpha=0.05$. Results. Some major differences between the two groups were observed: $23.35 \%$ of the rural and $15.75 \%$ of the city seniors did not exercise $(\mathrm{p}=0.0008)$; rural seniors smoked more $(16.40 \%)$ than city seniors $(7.53 \% ; \mathrm{p}=0.0225)$ and drank more units of alcohol at one time and tended to consume more animal protein. Conclusions. The findings suggest that social policies and local programs aimed at improving quality aging should take into account local differences between rural and urban senior communities and tailor actions accordingly. Rural seniors need more interest and support from both government institutions and social organizations.

Keywords: diet, alcohol consumption, physical activity, elderly, aging

\section{Streszczenie}

Wprowadzenie. W Polsce osoby starsze $(60+)$ mieszkające w miastach często mogą liczyć na wsparcie organizacji zajmujących się problemami zdrowotnymi seniorów. Natomiast obszary wiejskie wydają się być pod tym względem zaniedbane. Dlatego za cel badań przyjęto uzyskanie danych na temat wybranych zachowań zdrowotnych seniorów mieszkających na terenach miejskich i wiejskich. Ocenie poddano aktywność fizyczną, zachowania żywieniowe, palenie papierosów oraz spożycie alkoholu. Materiał i metody. Badania przeprowadzono w Polsce, wśród osób w wieku powyżej 60. lat mieszkających na wsi $(\mathrm{n}=128)$ oraz w mieście $(n=146)$. Posłużono się metodą sondażu diagnostycznego, z wykorzystaniem techniki ankiety. Różnice pomiędzy mieszkańcami miast i wsi oceniono za pomocą testu istotności dla dwóch wskaźników struktury na poziomie istotności $\alpha=0,05$. Wyniki. Zaobserwowano istotne statystycznie różnice pomiędzy badanymi grupami: liczniejsza grupa seniorów wiejskich 23,35\% niż miejskich $(15,75 \%)$ nie jest aktywna fizycznie $(\mathrm{p}=0,0008)$; starsi mieszkańcy wsi palą więcej $(16,40 \%)$ niż miejscy seniorzy $(7,53 \% ; p=0,0225)$, wypijają jednorazowo więcej jednostek alkoholu i spożywają większe ilości białka zwierzęcego. Wnioski. Wyniki sugerują, że polityka społeczna i lokalne programy mające na celu poprawę jakości starzenia się powinny uwzględniać różnice pomiędzy wiejską i miejską społecznością osób starszych. Seniorzy mieszkający na wsi potrzebują większego zainteresowania i wsparcia zarówno ze stronny instytucji rządowych jak i organizacji społecznych.

Słowa kluczowe: dieta, spożycie alkoholu, aktywność fizyczna, osoby starsze, starość

Omelan AA, Zielińska I, Wziątek B, Bielinis E, Podstawski R. Health-related behaviors of seniors in rural versus urban areas: a cross-sectional study. Health Prob Civil. 2020; 14(1): 1-8. https://doi.org/10.5114/hpc.2020.93293

Address for correspondence / Adres korespondencyjny: Aneta Anna Omelan, Department of Tourism, Recreation and Ecology, University of Warmia and Mazury in Olsztyn, Michała Oczapowskiego 5, 10-719 Olsztyn, Poland, e-mail: aneta.omelan@uwm.edu.pl, phone: +48 895233456

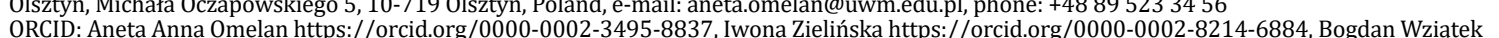

ORCID: Aneta Anna Omelan https://orcid.org/0000-0002-3495-8837, Iwona Zielińska https://orcid.org/0000-0002-8214-6884, Bogdan Wziątek
https://orcid.org/0000-0001-5625-4956, Ernest Bielinis https://orcid.org/0000-0002-6384-4898, Robert Podstawski https://orcid.org/0000-0002-1492-252X

Copyright: (C) Pope John Paul II State School of Higher Education in Biała Podlaska, Aneta Anna Omelan, Iwona Zielińska, Bogdan Wziątek, Ernest Bielinis, Robert Podstawski. This is an Open Access journal, all articles are distributed under the terms of the Creative Commons Attribution-NonCommercial-ShareAlike 4.0 International (CC BY-NC-SA 4.0) License (http://creativecommons.org/licenses/by-nc-sa/4.0/), allowing third parties to copy and redistribute the material in any medium or format and to remix, transform, and build upon the material, provided the original work is properly cited and states its license. 


\section{Introduction}

In Poland in 2017, older people constituted over 24\% of the general population [1]. In old age it is very important to maintain a low level of disability, high level of independent physical and mental function and active involvement and interest in life in order to achieve so called "successful aging" [2]. A healthy lifestyle is often believed to be the only reasonable strategy for quality aging [3]. Typically, health-oriented behavior includes sensible eating, physical activity (PA), and the avoidance of stimulants, especially alcohol and cigarettes. Research conducted among citizens over 60 show that the risk of loss of health and the aggravation of aging in elderly populations is primarily connected with negligence in the three above-mentioned spheres [4]. The selfrating of successful aging depends also on other factors, like cultural norms and values [5]. In a sense, the urban and rural seniors can be regarded as representing different cultures, with very different lifestyles.

Eastern Poland is the oldest region of the country demographically. Our study focused particularly on the north-eastern region of Poland because it is very much under-researched compared to other Polish regions. Elderly people in this region make up almost $40 \%$ of the population [6]. The group analyzed was compared with seniors living in cities in the same region. The aim was to obtain empirical data on exercise, eating habits, smoking and consumption of alcohol among seniors living in urban areas and traditional Polish villages to identify similarities and differences in health-oriented behaviors.

\section{Material and methods}

The study was conducted from January to March 2017 among people over 60 living in the countryside and in the city in the province of Warmia-Masuria in north-eastern Poland. A total of 400 seniors were selected but 76 potential respondents could not be reached and 50 further subjects refused to participate. Eventually 274 seniors from urban and rural areas took part in the study. The rural sample was composed only of those elderly who have spent their entire lives in traditional agricultural villages and have no permanent links with an urban environment. For the urban sample we selected respondents who have lived their entire adult life in the city. A self-reported health data method was employed in the study, using the Pen and Paper Personal Interview (PAPI) approach. The questionnaire was developed using the Questionnaire of Eating Behavior (QEB), Alcohol Use Disorders Identification Test (AUDIT) and the World Health Organization (WHO) recommendations on physical activity for seniors. It consisted of demographics and three thematic parts: physical activity, smoking and alcohol consumption, and eating habits. The information was completed by research assistants in face-toface interviews with the participants. The results were processed with the aid of STATISTICA v.12 software using a significance test of two structure coefficients at a significance level of $\alpha=0.05$.

$86.9 \%$ of the respondents were between 60 and 74 years old. Women were predominant in the group (74.10\%), with a greater gender disparity among seniors living in the city, where there were significantly more women $(81.51 \%)$ than men. There are two reasons for this overrepresentations of women: first, there are significantly more senior women than senior men in the region [7] and second, men were much more reluctant to participate in the study. More than half of the respondents in rural areas received only basic (primary) or vocational education (33.59\% and $26.56 \%$ respectively), compared to just over $12 \%$ of the city respondents representing a similar education level. Seniors from rural and urban areas have similar financial situations - mostly good or average. More than half of the respondents are married, but there are more older couples in the villages (74.21\%) than in the city (50\%) (Table 1$)$.

Table 1. Demographic characteristics of the respondents

\begin{tabular}{|c|c|c|c|c|c|c|}
\hline & \multicolumn{2}{|c|}{ City $(n=146)$} & \multicolumn{2}{|c|}{ Village $(n=128)$} & \multicolumn{2}{|c|}{ Total $(n=274)$} \\
\hline & $\mathbf{N}$ & $\%$ & $\mathbf{N}$ & $\%$ & $\mathbf{N}$ & $\%$ \\
\hline \multicolumn{7}{|c|}{ Gender } \\
\hline Women & 119 & 81.51 & 84 & 65.62 & 203 & 74.10 \\
\hline Men & 27 & 18.49 & 44 & 34.38 & 71 & 25.90 \\
\hline \multicolumn{7}{|c|}{ Age } \\
\hline 60-74 yrs & 119 & 81.51 & 119 & 92.97 & 238 & 86.90 \\
\hline 75-89 yrs & 27 & 18.49 & 9 & 7.03 & 36 & 13.10 \\
\hline \multicolumn{7}{|c|}{ Education } \\
\hline Higher & 46 & 31.50 & 26 & 20.31 & 72 & 26.28 \\
\hline Secondary & 82 & 56.16 & 25 & 19.54 & 107 & 39.06 \\
\hline
\end{tabular}




\begin{tabular}{|c|c|c|c|c|c|c|}
\hline Vocational & 11 & 7.55 & 34 & 26.56 & 45 & 16.43 \\
\hline Primary & 7 & 4.79 & 43 & 33.59 & 50 & 18.23 \\
\hline \multicolumn{7}{|c|}{ Economic status } \\
\hline Very good & 12 & 8.23 & 3 & 2.35 & 15 & 5.50 \\
\hline Good & 70 & 47.94 & 52 & 40.62 & 122 & 44.50 \\
\hline Average & 61 & 41.78 & 67 & 52.35 & 128 & 46.70 \\
\hline Bad & 3 & 2.05 & 6 & 4.68 & 9 & 3.30 \\
\hline \multicolumn{7}{|c|}{ Marital status } \\
\hline Married & 73 & 50.00 & 95 & 74.21 & 168 & 61.30 \\
\hline Single & 73 & 50.00 & 33 & 25.79 & 106 & 38.70 \\
\hline \multicolumn{7}{|c|}{ Occupational status } \\
\hline Working & 17 & 11.64 & 14 & 10.94 & 31 & 11.30 \\
\hline Not working & 129 & 88.36 & 114 & 89.06 & 243 & 88.70 \\
\hline
\end{tabular}

\section{Results}

More seniors in rural areas than in urban areas did not exercise ( $\mathrm{p}=0.0005) .26 .56 \%$ of the senior rural population, and $16.44 \%$ of the senior urban population exercise every day; $24.22 \%$ of the country seniors exercise a few times a week. The number is lower by more than half in comparison to urban seniors (54.79\%). Significant differences were observed between the groups $(\mathrm{p}=0.008, \mathrm{p}=0.01960$ and $\mathrm{p}<0.0001$, respectively). The largest group, regardless of the place of living, spends 1-2 hours per week on exercising. Significantly more seniors from the cities $(\mathrm{p}=0.0005)$ exercise $2-4$ hours per week. In both groups the most commonly chosen form of exercising is walking. Gymnastics and aerobic, on the other hand, are the least popular activities. A large number of rural seniors (38.57\%) dance, compared to only just over $5 \%$ of city seniors $(p=0.0001)$. Urban seniors are significantly more likely to cycle $(13.45 \%)$ than the rural ones $(1.43 \% ; \mathrm{p}=0.0001)$ (Table 2).

Table 2. Exercising*

\begin{tabular}{|c|c|c|c|c|c|c|c|}
\hline & \multicolumn{6}{|c|}{ Respondents } & \multirow{3}{*}{$\mathbf{p}$} \\
\hline & \multicolumn{2}{|c|}{ City $(n=146)$} & \multicolumn{2}{|c|}{ Village $(n=128)$} & \multicolumn{2}{|c|}{ Total $(n=274)$} & \\
\hline & $\mathbf{N}$ & $\%$ & $\mathbf{N}$ & $\%$ & $\mathbf{N}$ & $\%$ & \\
\hline \multicolumn{8}{|c|}{ Frequency } \\
\hline None & 23 & 15.75 & 41 & 32.03 & 64 & 23.35 & 0.0008 \\
\hline$<$ Once a month & 6 & 4.12 & 10 & 7.81 & 16 & 5.84 & 0.0961 \\
\hline Once a week & 13 & 8.90 & 12 & 9.38 & 25 & 9.12 & 0.4430 \\
\hline A few times a week & 80 & 54.79 & 31 & 24.22 & 111 & 40.51 & $\mathrm{p}<0.0001$ \\
\hline Everyday & 24 & 16.44 & 34 & 26.56 & 58 & 21.18 & 0.01960 \\
\hline \multicolumn{8}{|c|}{ Time/per week } \\
\hline $\mathbf{O h}$ & 23 & 15.75 & 41 & 32.03 & 64 & 23.35 & 0.0016 \\
\hline$<1 \mathrm{~h}$ & 19 & 13.01 & 22 & 17.19 & 41 & 14.97 & 0.3558 \\
\hline 1-2 h & 60 & 41.10 & 50 & 39.06 & 110 & 40.15 & 0.7361 \\
\hline 2.1-4 h & 39 & 26.71 & 13 & 10.16 & 52 & 18.98 & 0.0005 \\
\hline 4.1-6 h & 5 & 3.43 & 2 & 1.56 & 7 & 2.55 & 0.3465 \\
\hline \multicolumn{8}{|c|}{ Most popular forms of exercising** } \\
\hline $\begin{array}{c}\text { Walking/ Nordic } \\
\text { walking }\end{array}$ & 75 & 63.03 & 40 & 57.14 & 115 & 60.85 & 0.1573 \\
\hline Dancing & 6 & 5.03 & 27 & 38.57 & 33 & 17.46 & 0.0001 \\
\hline Cycling & 16 & 13.45 & 1 & 1.43 & 17 & 8.99 & 0.0001 \\
\hline Gymnastics/aerobic & 4 & 3.36 & 2 & 2.86 & 6 & 3.17 & $0.4047-$ \\
\hline Jogging & 18 & 15.13 & 0 & - & 18 & 9.52 & - \\
\hline
\end{tabular}

Notes:

*The data presented in this section was partially discussed in another article on the physical activity of seniors.

${ }^{* *} \mathrm{n}=189$; the question was answered only by those respondents who admitted to exercising. 
There were no statistically significant differences between the groups in frequency of alcohol consumption. Rural seniors often have one unit of alcohol at a time (44.0\%; $\mathrm{p}=0.0482$ ), while urban dwellers have two to three units (58.33\%; $\mathrm{p}=0.0008)$. People living in the countryside drink more than five units of alcohol at one time $(10.0 \%$ compared to $0.92 \% ; \mathrm{p}=0.0007)$. There are almost twice as many cigarette smokers among rural respondents than the urban ones $(16.40 \%$ vs $7.53 \%$; $=0.0225)$ (Table 3).

Table 3. Smoking and alcohol consumption

\begin{tabular}{|c|c|c|c|c|c|c|c|}
\hline & \multicolumn{6}{|c|}{ Respondents } & \multirow{3}{*}{$\mathbf{p}$} \\
\hline & \multicolumn{2}{|c|}{ City $(n=146)$} & \multicolumn{2}{|c|}{ Village $(n=128)$} & \multicolumn{2}{|c|}{ Total $(n=274)$} & \\
\hline & $\mathbf{N}$ & $\%$ & $\mathbf{N}$ & $\%$ & $\mathbf{N}$ & $\%$ & \\
\hline \multicolumn{8}{|c|}{ Frequency of alcohol consumption } \\
\hline Once a day & 1 & 0.68 & 4 & 3.12 & 5 & 1.82 & - \\
\hline 1-3 times a week & 10 & 6.84 & 6 & 4.68 & 16 & 5.83 & 0.4465 \\
\hline$>1$ once a month & 54 & 36.99 & 59 & 46.09 & 113 & 41.24 & 0.0128 \\
\hline 1-3 times a month & 43 & 29.46 & 31 & 24.21 & 74 & 27.00 & 0.3288 \\
\hline Abstinent & 38 & 26.03 & 28 & 21.87 & 66 & 24.08 & 0.4217 \\
\hline \multicolumn{8}{|c|}{ Units of alcohol consumed at one time* } \\
\hline 1 & 35 & 32.40 & 44 & 44.00 & 79 & 37.99 & 0.0482 \\
\hline $2-3$ & 63 & 58.33 & 38 & 38.00 & 101 & 48.55 & 0.0008 \\
\hline 4-5 & 9 & 8.33 & 8 & 8.00 & 17 & 8.17 & 0.9208 \\
\hline More than 5 & 1 & 0.92 & 10 & 10.00 & 11 & 5.29 & 0.0007 \\
\hline \multicolumn{8}{|c|}{ Smoking } \\
\hline Smokers & 11 & 7.53 & 21 & 16.40 & 32 & 11.68 & 0.0225 \\
\hline Non-smokers & 127 & 86.9 & 100 & 78.12 & 227 & 82.84 & 0.0520 \\
\hline Social smokers & 8 & 5.48 & 7 & 5.46 & 15 & 5.48 & - \\
\hline
\end{tabular}

${ }^{*} \mathrm{n}=208$; the question was answered only by those respondents who admitted to drinking alcohol.

$72.66 \%$ of respondents have three to four meals a day. Most respondents have regular meals (81.39\%) and at least one portion of fruits or vegetables a day. There are, however, statistically significant differences between the rural and urban group in dairy consumption ( $p=0.0468$ and $p<0.0001$ respectively). Significantly more senior villagers admit to having meat daily $(14.06 \%)$ compared to only $0.68 \%$ of city seniors $(<0.0001)$ and $82.82 \%$ of them eat animal products several times a week (Table 4 ).

Table 4. Eating habits

\begin{tabular}{|c|c|c|c|c|c|c|c|}
\hline & \multicolumn{6}{|c|}{ Respondents } & \multirow{3}{*}{$\mathbf{p}$} \\
\hline & \multicolumn{2}{|c|}{ City $(n=146)$} & \multicolumn{2}{|c|}{ Village $(n=128)$} & \multicolumn{2}{|c|}{ Total $(n=274)$} & \\
\hline & $\mathbf{N}$ & $\%$ & $\mathbf{N}$ & $\%$ & $\mathbf{N}$ & $\%$ & \\
\hline \multicolumn{8}{|c|}{ Number of meals per day } \\
\hline Three & 113 & 77.40 & 85 & 67.46 & 198 & 72.66 & 0.0326 \\
\hline Four-five & 33 & 22.60 & 43 & 33.59 & 76 & 27.34 & 0.0213 \\
\hline \multicolumn{8}{|c|}{ Regularity of meals } \\
\hline Yes & 119 & 81.50 & 104 & 81.25 & 223 & 81.39 & 0.9577 \\
\hline No & 27 & 18.50 & 24 & 18.75 & 51 & 18.61 & 0.9577 \\
\hline \multicolumn{8}{|c|}{ Fruit consumption } \\
\hline At least once a day & 109 & 74.66 & 95 & 74.22 & 204 & 74.46 & 0.4668 \\
\hline A few times a week & 29 & 19.86 & 27 & 21.09 & 56 & 20.44 & 0.4006 \\
\hline Occasionally & 8 & 5.48 & 6 & 4.69 & 14 & 5.10 & - \\
\hline \multicolumn{8}{|c|}{ Vegetables consumption } \\
\hline At least once a day & 104 & 71.24 & 84 & 65.63 & 188 & 68.62 & 0.1590 \\
\hline A few times a week & 38 & 26.02 & 42 & 32.81 & 80 & 29.2 & 0.1087 \\
\hline Occasionally & 4 & 2.74 & 2 & 1.56 & 6 & 2.18 & - \\
\hline \multicolumn{8}{|c|}{ Dairy consumption } \\
\hline At least once a day & 81 & 55.48 & 58 & 45.33 & 139 & 50.73 & 0.0468 \\
\hline A few times a week & 51 & 34.94 & 52 & 40.62 & 103 & 37.60 & 0.1664 \\
\hline
\end{tabular}




\begin{tabular}{|c|c|c|c|c|c|c|c|c|}
\hline Occasionally & 14 & 9.58 & 18 & 14.05 & 32 & 11.67 & $\mathrm{p}<0.0001$ \\
\hline \multicolumn{7}{|c|}{ Fish consumption } \\
\hline 3-4 times a week & 15 & 10.28 & 7 & 5.47 & 22 & 8.03 & 0.0719 \\
\hline Once a week & 63 & 43.16 & 52 & 40.62 & 115 & 41.97 & 0.3354 \\
\hline A few times a month & 46 & 31.5 & 49 & 38.28 & 95 & 34.67 & 0.1044 \\
\hline Occasionally & 22 & 15.06 & 20 & 15.63 & 42 & 15.3 & 0.4480 \\
\hline \multicolumn{7}{|c|}{ Animal protein in meals } \\
\hline Once a week & 5 & 3.43 & 4 & 3.12 & 9 & 3.28 & 0.3182 \\
\hline A few times a week & 140 & 95.89 & 106 & 82.82 & 246 & 89.78 & 0.0002 \\
\hline Everyday & 1 & 0.68 & 18 & 14.06 & 19 & 6.94 & $<0.0001$ \\
\hline
\end{tabular}

\section{Discussion}

Physical activity has a positive influence on physical and mental health and improves quality of life, allowing seniors to enjoy their independence [8]. In the group studied, $23.35 \%$ of all the participants never exercise. A significant difference was recorded between the two groups of seniors: $15.75 \%$ of the urban dwellers do not exercise, with twice that percentage in rural areas. Rural seniors seem to be less likely to undertake physical activities in a strict sense, that is, as a form of reflexive, health-enhancing activity. The WHO recommends the elderly engage in at least 150 minutes of moderate exercise, or 75 minutes of vigorous exercise, a week [8]. In the group studied only a few met these standards. In total, $61.69 \%$ of the respondents said they exercise daily or several times a week, but regret not spending enough time on these activities. This means that only one-fifth of all the respondents comply with WHO recommendations.

Similar to other findings on seniors' health [10], walking was the dominant form of exercising (Table 2). Polish seniors are particularly keen on Nordic walking [11], a gentle form of physical activity suitable for people over 60. None of the surveyed villagers jog. In the city however, this form of exercise is preferred by $14.29 \%$ of the respondents. As many as $38.57 \%$ of the rural seniors pointed to dancing as their most common form of keeping fit, while in the city just over $5 \%$ seniors dance. The reason for these differences may lie in the fact that dancing in rural areas has always played central social functions and folk festivals are often an important event in the agricultural cycle [12]. Cycling seems to be much more popular in the city, with a statistically significant difference noted. However, it is assumed through observations made in the countryside during the interviews, that the use of a bike was very widespread there. In rural areas, though, a bicycle is utilized more as a means of transport than as a form of activity undertaken in one's free time, and thus perhaps resulted in a much lower response rate in this regard.

Our findings indicate that place of residence may affect the amount and type of physical activities performed by seniors. In the city, more seniors exercise. Many factors, such as lifestyle and education play a role, but the shortage of sports facilities in the countryside as well as targeted activities organized by institutions may also be an important reason for lower exercise levels, not only among older people but also younger ones. Moreover, the countryside lacks general awareness-raising activities and programs enabling persons over 60 to participate in various forms of physical activity adapted to their psychophysical abilities.

In 2017, $24 \%$ of Polish citizens smoked cigarettes, and in the over 60 population, $30 \%$ of men and $19 \%$ of women smoke cigarettes [13]. In our study, $16.40 \%$ of rural seniors admitted to smoking, more than double the number in the urban group. The number of social smokers in both groups was the same. In total $11.68 \%$ of the respondents smoked. In comparison, in the US, $8.2 \%$ of people over 65 reported cigarette use every day [14]. In the north-eastern region of Poland the rural seniors in general are more likely to reach for a cigarette than their urban peers. Smoking remains a strong risk factor for premature mortality in older age and increases the risk of cardiovascular disease [15]. Seniors living in the city might be more aware of the benefits of a healthy lifestyle, potentially partially explaining the difference in the results. In addition, as discussed earlier, they are more likely to undertake physical activity, thus impacting their decision to limit or quit smoking.

Another stimulant we looked at in the study was alcohol, because aging has changed attitudes towards alcohol consumption by older people [16]. Alcohol abuse by an elderly person can lead to serious health consequences, and mixing alcohol with drugs can produce particularly serious side-effects [17]. The general amount and frequency of alcohol consumption decreases in older age groups, but problems related to alcohol consumption still occur in about $2-5 \%$ of people over 60 years of age. To compare, in the United States, about $5 \%$ of seniors are estimated to suffer from alcohol-related problems [17].

In the group of rural seniors analyzed, $21.87 \%$ abstained from alcohol. The result obtained in the northeastern region of Poland is similar to nationwide data. The report Alcohol Consumption in Poland in 2013 shows 
that among those over 60 years of age, $27 \%$ abstain, and the inhabitants of rural areas are less likely to drink alcohol than the urban population [18]. The State Agency for the Prevention of Alcohol-Related Problems defines "irresponsible consumption" as four units of alcohol consumed by men, and two by women [18]. The villagers most often drink one unit of alcohol, and the inhabitants of the city two to three. But in the countryside, $10 \%$ of respondents drink more than five units of alcohol at one time, whereas in the city less than $1 \%$ of the seniors do so. It is suggested that the reason for the difference lies in lifestyle, which also affects the so-called drinking culture [19]. Nevertheless, these findings contradict the general belief that frequent and excessive consumption of alcohol is mainly a problem among inhabitants of Polish rural areas.

Aging results in severe changes in the digestive system, which can significantly affect nutrition [20]. Chronic energy deficiency among the elderly often leads to increased hospital admissions and even mortality [21]. Healthy eating directly affects overall body function. Due to the increased incidences of chronic diseases in older age, appropriate dietary restrictions are often recommended. Nutrition guidelines for the elderly indicate that they should have four to five meals a day, and should include a variety of foods in their diet [22]. Among the villagers surveyed, $33.59 \%$ try to meet these recommendations, compared to $22.60 \%$ of urban seniors. Both groups do not differ much, though, in terms of the regularity of food intake - almost $82 \%$ of the seniors have regular meals. This result is similar to other studies conducted among Polish rural seniors [23].

The medical guidelines for the elderly emphasize the importance of fruit and vegetables as healthy foods that help maintain a proper weight and slow the process of aging and reduced likelihood of chronic disease [24]. According to the European Code Against Cancer, as many as $62 \%$ of Poles do not eat fruits and vegetables on a daily basis. Only $2 \%$ consume the recommended minimum of $400 \mathrm{~g}$ per day [25]. Both groups are alike in fruit and vegetable consumption. In general, the largest group of respondents said they eat fruit or vegetables at least once a day, which is a testimony to the dietary habits of the respondents. In the group surveyed $79.6 \%$ of the respondents eat vegetables and fruit six times a week. The quality of these products is a separate issue. From the interviews and from observations during the study it appears that in the countryside most of the respondents have orchards and vegetable gardens, so they have access to their own fresh produce.

Dairy products are very popular in both groups but more city seniors have them on a daily basis. Half of all the respondents admit to having dairy products several times a week. In this case as well, the quality of the products makes a difference. In the traditional villages where the research was conducted, milk, eggs and dairy products can be bought directly from farmers. The products are usually fresh and made according to local recipes, without artificial additives. In cities however, access to such high quality products is rather limited.

Fish consumption is on a similar level in the countryside and in the city: seniors most often have fish once a week. This is probably connected with the Catholic tradition of fasting on Fridays, which is deeply rooted in Poland. All the respondents eat meat, but older villagers consume animal protein more often, i.e., every day or several times a week. Meat dishes are popular with the elderly, regardless of their place of residence. The preference seems to be associated with traditional eating habits. Therefore, it might be more difficult for older people than for younger generations to change their lifelong habits and replace meat with other products.

Our research focused on those elements that are widely believed to comprise a so-called healthy lifestyle. Urban and rural environments are surely very different locations, with community norms, outlooks and social ties attached to them that all influence the heath-related behaviors of seniors in those environments. The results indicate that the elements of a healthy lifestyle differ between older rural and urban dwellers. The specific lifestyles of rural seniors, and their physical activities in particular, should not be considered merely in terms of will and choice but also in relation to the possibilities and limitations faced by rural inhabitants. Anthony Giddens, a sociologist, rightly points out that class divisions, inequality, and social exclusions can be defined in terms of differential access to forms of self-actualization and empowerment [26]. From this point of view, the concept of life chances can be useful in explaining differences between rural and urban seniors' lifestyles. Life chances determine the realization of life choices and are connected to a particular life situation, not only to the economic aspect but also to values and norms, patterns and social relationships which enable or disable the realization of life choices [27]. Life choices and needs, and life chances seem to be interdependent. Allowing greater access and support is particularly important in rural areas, where almost $32 \%$ of all Polish citizens over 65 live [28]. Therefore, targeted programs that account for differences between seniors' environments and their lifestyles, are needed to improve the life quality of this group and support the practice of successful aging.

\section{Conclusions}

The differences in health-related behaviors of rural and urban seniors indicate that programs promoting quality aging need to be tailored to different environments and lifestyles of the elderly. However, the features of 
lifestyle chosen for this very study influence successful aging only to a certain extent. There are other significant factors that could be studied in future research, such as sexual activity, access to facilities or social engagement on the quality of seniors' lives. Urban seniors might have much better access to community centers, seniors' associations, and shopping malls, but in villages the parishes that are central for community life in Polish rural areas might prevent social isolation and create closer ties between locals, thus affecting satisfaction and successful aging. It would be interesting to explore these and other elements further across Poland as well as other countries to inform details of actions and policies aimed at older citizens.

\section{References:}

1. Central Statistical Office. [Situation of elderly people based on the research conducted by Central Statistical Office]. Warszawa: GUS; 2018 (in Polish).

2. Strawbridge WJ, Wallhagen MI, Cohen D. Successful aging and well-being: self-rated compared with Rowe and Kahn. Gerontologist. 2002; 42(6): 727-733. https://doi.org/10.1093/geront/42.6.727

3. Ostrowska A. [Health and lifestyle]. Warszawa: IFiS PAN; 1999 (in Polish).

4. Reed DM, Foley DJ, White LR, Heimovitz H, Burchfiel CM, Masaki K. Predictors of healthy aging in men with high life expectancies. American Journal of Public Health. 1998; 88: 1463-1468. https://doi.org/10.2105/AJPH.88.10.1463

5. Steward JM, Auasis M, Belanger E, Phillips SP. Comparison of self-rated and objective successful ageing in an international cohort. Ageing and Society. 2019; 39(7): 1317-1334.

https://doi.org/10.1017/S0144686X17001489

6. Białobrzeska K, Głuszak B, Kurkowski C, Maciejewska M. [The disappearance of the bench: the determinants of the activity of seniors in rural areas]. Kraków: Impuls; 2016 (in Polish).

7. Statistical Office in Olsztyn. [Demographic situation of warmińsko-mazurskie voivodship in 2017] [Internet]. Olsztyn: Statistical Office; 2018 [cited 2018 Nov 27]. Available from: https://olsztyn.stat.gov.pl/ en/publications/population/demographic-situation-of-warminsko-mazurskie-voivodship-in-2017,4,1.html (in Polish).

8. Lampinen P, Heikkinen RL, Kauppinen M, Heikkinen E. Activity as a predictor of mental well-being among older adults. Aging \& Mental Health. 2006; 10(5): 454-466. https://doi.org/10.1080/13607860600640962

9. World Health Organization. [Physical activity and older adults. Recommended levels of physical activity for adults aged 65 and above] [Internet]. Geneva: WHO; 2015 [cited 2018 Sep 25]. Available from: https://who.int/dietphysicalactivity/olderadults/en/

10. Harris TJ, Owen CG, Victor CR, Adams R, Cook DG. What factors are associated with physical activity in older people, assessed objectively by accelerometry?. British Journal of Sports and Medicine. 2009; 43: $442-450$. https://doi.org/10.1136/bjsm.2008.048033

11. Jurczak D, Przybysz A. Physical activity of elderly people on the example of the course participants at the University of the Third Age in Krosno. Health Prob Civil. 2014; 8(2): 20-27.

https://doi.org/10.5114/hpc.2014.57074

12. Lange R. On differences between rural and the urban: traditional Polish peasant dancing. Yearbook of the International Folk Music Council. 1974; 6: 44-51. https://doi.org/10.2307/767724

13. Trząsalska A, Staszyńska M, Krassowska U. [Raport from Polish national survey on attitudes towards smoking] [Internet]. Warszawa: Główny Inspektorat Sanitarny; 2017 [cited 2018 Oct 17]. Available from: https://gis.gov.pl/wp-content/uploads/2018/04/Postawy-Polak\%C3\%B3w-do-palenia-tytoniuRaport-2017.pdf (in Polish).

14. Wang TW, Asman K, Gentzke AS, Cullen KA, Holder-Hayes E, Reyes-Guzman C, et al. Tobacco product use among adults - United States, 2017. Morbidity and Mortality Weekly Report. 2018; 67(44): 1225-1232. https://doi.org/10.15585/mmwr.mm6744a2

15. Gellert C, Schöttker B, Brenner H. Smoking and all-cause mortality in older people. Systematic review and meta-analysis. Archives of Internal Medicine. 2012; 172(11): 837-844. https://doi.org/10.1001/archinternmed.2012.1397

16. Harbat B. Problems connected with alcohol use in elderly. Postępy Nauk Medycznych. 2011; 8: 701-704.

17. Ross S. Alcohol use disorders in the elderly. Primary Psychiatry. 2005; 12(1): 32-40.

18. TNS. [Alcohol consumption in Poland (2013) Research report]. Warszawa: TNS; 2013 (in Polish).

19. Heath DB. An anthropological view of alcohol and culture in international perspective. In: Heath DB., editor. International handbook on alcohol and culture. Westport: Greenwood Press; 1995. p. 328-347.

20. Leslie W, Hankey C. Ageing, nutritional status and health. Healthcare. 2015; 3(3): 648-658. https://doi.org/10.3390/healthcare3030648 
21. Kalaiselvi S, Arjumand Y, Jayalakshmy R, Gomathi R, Pruthu P, Palanivel C. Prevalence of under-nutrition, associated factors and perceived nutritional status among elderly in a rural area of Puducherry, South India. Archives of Gerontology and Geriatrics. 2016; 65: 156-160. https://doi.org/10.1016/j.archger.2016.03.003

22. Gabrowska E, Sporadyk M. Nutrition guidelines for the elderly. Gerontologia Polska. 2006; 14(2): 57-62.

23. Burzyńska M, Kępa M, Bryla M, Maniecka-Bryla I. [Self-rated health status and health behaviors in the elderly in rural areas]. In: Szukalski P., editor. [Population ageing and solidarity between generations]. Łódź: Uniwersytet Łódzki; 2014. p. 181-196 (in Polish).

24. Nicklett EJ, Kadell AR. Fruit and vegetable intake among older adults: a scoping review. Maturitas. 2013; 75(4): 305-312. https://doi.org/10.1016/j.maturitas.2013.05.005

25. Wojtasiński Z. [Experts say: Fruit and vegetables consumption in Poland is getting down] [Internet]. Warszawa: FUNDACJA PAP; 2015 [cited 2018 Sep 27]. Available from: http://naukawpolsce.pap.pl/ aktualnosci/news\%2C404103\%2Ceksperci-niepokojaco-spada-spozycie-warzyw-i-owocow-w-polsce.html (in Polish).

26. Giddens A. Modernity and self-identity. Self and society in the late modern age. Stanford California: Stanford University Press; 1991.

27. Dahrendorf R. A new world order? Problems and prospects of international relations in the 1980s. Accra: University of Ghana; 1979.

28. Centrum Badania Opinii Społecznej. [A socio-demographic portrait of seniors. Report no. 160/2016]. Warszawa: CBOS; 2016 (in Polish). 